\title{
AUTHENTIC ASSESSMENT IN LITERAL AND INFERENTIAL READING COMPREHENSION FOR UNIVERSITY STUDENTS
}

\author{
Dwi Fita Heriyawati \\ Kanjuruhan University of Malang \\ dwifitaheriyawati@yahoo.com
}

\begin{abstract}
The teaching of English as a foreign language in Indonesia is widely developed time to time. In the teaching of English, reading comprehension has an important role, because through reading the text the students will acquire the knowledge of science and technology. Furthermore, the teachers have also have to measure the students' performance in comprehending the reading text. The use of authentic assessment in the literal and inferential reading comprehension can help the students and also the teachers in comprehending what they learn in the text. The authentic assessment will reduce the tension of the students while they do reading test. Teachers also can implement the teaching learning process and the assessment efficiently. This paper aim to give some contribution to the readers how to select a good reading assessment that should be given for the university students. Hopefully, this paper can give a contribution to the teachers in Indonesia to be wise in selecting a good reading text and reading assessment in order to get the purpose of reading itself.
\end{abstract}

Keywords: Authentic assessment, reading comprehension, literal and inferential comprehension.

English is the international language in the world. All the countries are using English as their first, second or foreign language. Therefore, many people have to learn English. In Indonesia, English is taught from the elementary level until the university level. English has been becoming the compulsory subject being taught for all the students in all levels of education in Indonesia.

Concerning with the very important English to be taught in the school, the teachers have to teach all the language skills. They are listening, speaking,reading, and writing. All the language skills must be acquired by the students. Furthermore, after the teaching of English in the school, the teachers have to measure the students' ability in acquiring English. Related with the assessment to the students ability, here I am focusing more in the assessing the students ability in comprehending the reading text. In this case, I try to assessing the student ability in comprehending literal and inferential meaning from the reading text.

The aim of this paper is to describe the use and the implementation of authentic assessment in literal and inferential reading comprehension. The teacher has to be aware to use the authentic assessment in the real reading text. The teacher must be considering the material used in assessing the students' reading comprehension. The use of authentic assessment in literal and inferential reading comprehension is also to measure the application of reading knowledge in an appropriate way. The teacher has to decide what a good reading test is, and the teacher has to know what appropriate model to measure the stu- 
dents' comprehension in literal and inferential comprehension is. Authentic assessment also makes the students learn efficiently and the teachers also teach efficiently. Moreover, the uses of authentic assessment also help the teacher and the students to understand their difficulty easily, because they use very efficient assessment.

The knowledge of authentic assessment in reading comprehension is in line with Grabe \& Stoller (2002) who stated how the major goal of foreign language reading assessment should be introduced to assessment practices that incorporate the following: fluency and reading speed, automaticity and rapid word recognition, search processes, vocabulary knowledge, morphological knowledge, syntactic knowledge, text structure awareness, and discourse organization, main ideas comprehension, recall of relevant details, inferences about text information, strategic processing abilities, summarization, synthesis skills and evaluation, and lastly, critical reading. Reading assessment should be based on real world reading needs and activities.

The implementation of authentic assessment in reading comprehension is not only to know what the students do, but also it is to know what the students learn in the classroom. By implementing the authentic assessment the teacher can measure the students' literal and inferential comprehension. The teachers measuring the students reading comprehension by give the students homework, regular assignment, portfolio, mid-test, and final test. The progress of the students' competence will be recorded by the teacher and then the teacher will calculate the result of student score.

In giving the students authentic assessment, the teacher should be selective in choosing the material for teaching reading comprehension. The formulation of the question in the reading test, homework, assignment, mid-test and final test should fulfill the requirement of a good test. They include the lit- eral and inferential question related with the reading material being taught. Concerning with literal and inferential question in reading test, we have to know the characteristic of the test itself. Literal, inferential, and evaluative questions are the three main sections of a comprehension task. It is regularly used to assess the level of a person's comprehension skill. Literal is mainly the easiest group. Inferential is the medium level, and the evaluative is the difficult part. However, some people do not consider these as their levels. It depends on their comprehension skills. Literal is a question that can be answered directly from the text. The answer is already there. It is just if you can identify it. Sometimes you would need to word it. Whereas Inferential is question that cannot be answered straight from the text. You will need to think about it and read over the text to see. The text only tells you hints and clues. Sometimes you would need to word it. Then the most difficult part of the test is evaluative. Evaluative is questions that are very similar to inferential questions. However, evaluative sort of sums up the text and ask you to judge something of the text such as the meaning, truth, answer, opinion and etc. Sometimes you would need to word it.

To clarify the term kind of reading test above, here is the very simple example of the literal, inferential, and evaluative reading comprehension assessment.

\section{Text Example:}

"Tim was desperate to leave the classroom. He was bored. He watched the clock wisely. It was only 12:30pm. He had to wait for an hour until the lesson is finished. He was learning maths - algebra. Mr. Howl was making him do heaps of boring and hard equations. Suddenly, he had an idea. Tim hid under his table and crawled onto the floor. He headed for the door and sneakily left."

\section{Literal:}

1. What did Tim do while Mr. Howl was 
making him do maths work?

Tim was looking at the clock wisely. (Direct answer is on the text)

2. What was the time?

It was 12:30pm then. (Answer already on the text)

\section{Inferential:}

1. When can Tim leave the classroom? Tim can leave the classroom by 1:30pm. (Using the hints on the text)

2. Why did he look at the clock wisely? Tim was looking at the clock wisely because he wanted to get out of the classroom. (Using the hints on the text))

\section{Evaluative:}

1. What do you think Tim's idea will work? Explain your answer.

I don't think Tim's idea will work because Mr. Howl must of notice during that hour...

2. Why would Tim hide under the table?

Tim hid under the table because he didn't want to be seen. (Using commonsense + hints on the text + your own opinion)

After knowing the example of reading assessment then, the teacher should be consistent in giving the students assignment, homework, mid-test and final test. The teacher should record all the students' progress. From portfolio the teacher also can know the progress of the students. The students can learn effectively and they not only know what they do in reading, but also they learn something from their reading. From literal comprehension the students can directly understand the context of the text because the information they need already stated in the text explicitly. Whereas, in the inferential comprehension, need the ability from the students to understanding the depth information from the text. The student's analysis and critical thinking is very important in this case. They need to analyze deeper about the content of the text. They can do it by using main ideas comprehension, recall of relevant details, inferences about text information, strategic pro- cessing abilities, summarization, synthesis skills and evaluation, and also reading the text many times in order to get more information needed. A good reading comprehension test should fulfill the kind of the reading test. They are literal, inferential, and evaluative. By regular practices of authentic assessment the student will easily understanding the meaning of the text implicitly and explicitly. Therefore, the teaching learning process of reading comprehension will be fun and of course it will reduce the student's tension in the reading comprehension course.

In conclusion, the use of authentic assessment really makes the students learn from the text they read. Besides, the teacher also finds the efficient technique to assess the student's comprehension from the text. A good reading test is a test which measures the ability of the students and it is such kind of the application knowledge in reading comprehension itself. In other words, the authentic assessment measures what the students learn not only what they do in reading. In contrast with the evaluation which only measures the students reading ability in particular time. So, the goal for reading comprehension cannot reach well in evaluation. Otherwise, in authentic assessment the goal of reading that is for getting the knowledge can reach well. Because in this authentic assessment the teacher really measure the ability of the students in comprehending the text literally and inferentially through the stretch of the word, vocabulary analysis,main ideas comprehension, recall of relevant details, inferences about text information, strategic processing abilities, and summarizing, and all of these are formulated well in the reading test question. The composition of the reading test in the authentic assessment should be appropriate with the text given to the students.

Hopefully, by using the authentic assessment the students will enjoy reading all of the materials given by the teacher in the reading comprehension courses, and they can learn 
may thing from the reading text that they read. Further, the students reading habit will be well established because they enjoy reading without being worried about the result of

\section{REFERENCES}

Carol Beaumont. (2002).Alternative Assessment for Transitional Readers. Bilingual Research Journal, 26:2 Summer 2002.

Grabe, W., \& Stoller, F. L. (2002). Teaching and researching reading. Harlow: Pearson Education Limited.

Jorge Hugo Muñoz Marín. (2009.Exploring Teachers' Practices for Assessing Reading Comprehension Abilities in English their reading test. Then, the real goal of reading to get the knowledge from the text being read can be reach well.

as a Foreign Language.Profile Vol. 11, No. 2, 2009. Issn 1657-0790. Bogotá, Colombia. Pages 71-84

Kristina C. Breaux. 2008. Interpreting Performance on the Reading Comprehension Subtest. Pearson Education, Inc.

http:/ / wiki.answers.com/Q/What_are_Literal_and_Inferential_and_Evaluative_Questions. accessed on December 21, 2012. 